\title{
食料・農業に関する北東アジア連携の基盤とは何か
}

飯國 芳明（高知大学）

\section{What are Bases for The Cooperation among Northeastern Asian Economies as Regards Food and Agricultural Activities?}

Yoshiaki Iiguni (Kochi University)

This paper aims to investigate the bases for the existing cooperation in the field of agricultural activities among the Northeastern Asian economies comprising Japan, Korea, Taiwan, and China. The main results are as follows: the first cooperation basis stems from the fact that all the four abovementioned economies are located in the Asian monsoon area, and thus have a similar agricultural structure that is based on rice plantation. The second basis is the economic features of a high income economy and

\section{1. はじめに}

本稿の課題は，北東アジアに抢ける連携を支える 基盤の構造を明らかにすることにある.

近年, 農業経済学関係の学会に打いて北東アジア をひとつの括りとして捉えるシンポジゥムが相次い で開催された。地域農林経済学会の 2006 年度シン ポジウム「グローバリゼーションと地域農業・農政 の展望」や日本農業経済学会の 2007 年度の大会シ ンポジウム「経済グローバリゼーションと農業一東 アジア経済圏連携の可能性一」などがそれに当たる. いずれも本稿で検討する北東アジアの連携が主要な 課題のひとつとなっている.

しかし, 北東アジアの連携がどのよらな基盤に立 脚するのかについての分析は極めて限られている. むしろ, 対外的な交渉の過程で日本が孤立した結果, 連携を求めるケースが多い. 連携条件が整ってきた から，連携を進めるといらょり，その必要性，とり わけ日本からみた必要性，が高まっているから連携 を強化すべしという立場が支配的である。

連携の基盤のひとつとして，アジア・モンスーン 地域が指摘されることがあるが，その特性は北東ア pure food import. Currently, only China does not fulfill this condition. The possibility that China will fulfill it after becoming an advanced economy is not unlikely. The last basis is the intimate food network operating among the above economies, which has shown steady increase over the last two decades. The issue of food security, including production process monitoring, that emerged in 2008 regarding food exported from China has also been a factor that has strengthened the food network.

ジアに限定されない。また，域内の食料貿易の増大 を連携の根拠としても，それだけでは，連携の必要 性の一部の関係しか説明しえないなぞ，連携を支え る論理は必ずしも明らかにされていない。

敃そらく, 北東アジアの連携はいくつかの要因に 支えられて敃り，それらが複層的な構造をもってい ると考光られる ${ }^{1)}$.

そこで, 本稿では, その構造の解析を統計データ に基づいて進める。また，北東アジアの連携がこれ までのように日本が必要とする連携から，北東アジ アの各経済圏（ここでは日本，韓国，台湾，中国） が揃って必要とする連携へと構造変化しつつあると の仮説の下で，その実態の変化を跡づける.

\section{2. 農業・食料をめぐる関係の変化}

北東アジア農業の連携の必要性は 1990 年代から議 論されてきた．今村他（1994）は農業構造の比較分 析からその類似性に着目し, 研究活動の連携の必要 性を説いている。すなわち，北東アジアに位置する 4 つの経済圈を形成する日本，中国，韓国，台湾に 共通する特質として, 1）農地改革の実施, 2）アジア・ 
モンスーン，3）農業経営と集団との連携の存在を挙 ゲ，これを連携の根拠とする。 また，相互の比較を もとに, 自作農業体制からの脱却, 親子代々農業の 脱却，企業的性格を内包する経営主体の創設，さら には，転用規制の強化なぞの提案を行っている.

1990 年代後半以降になると, 北東アジア農業構 造の類似性とは別に国際農業交渉上の必要性から政 治的な連携を強調する主張が目立つようになる。例 党ば，辻井（2000）は，WTO の交渉はアメリカと EUがへゲモニーを握って拉り, 途上国にとって不 公平であり，アジアに共通する多面的機能を衰失さ せるものとして批判する。この状況を突破するため に日本主導でアジア諸国との連携が不可欠とする. また，堀口（2000）は，WTO に打汀る交渉のあり 方として，「アジアの途上国の動きに我々は注目寸 べきであろう」とし，「日本が主張する農業の多面 的機能は, アジア・モンスーン地域の稲作国にかな り共通する」と指摘する ${ }^{2)}$.

日本が北東アジアや広くアジア全域との連携を必 要とする背景には, ウルグアイ・ラウンド交渉に特 いて日本のパートナーが不在であり, 孤立していた 状況がある，そこで，東アジアやモンスーン・アジ アといった地域を想定し，その同質性を根拠に連携 し, 交渉力を強めたいとの意向が強まった。しかし， 当時のアジア地域の多くは途上国や新興国であり, 途上国に対する特別措置の利益が大きく，日本とと もに交渉する戦略は必ずしも魅力的ではなく, 連携 の実現性は高くなかった.

こらした状沉に変化が生じるのは 21 世紀に入っ てからである。

\section{3. 分析方法}

以下では北東アジアの連携を支える要因の変化と その構造分析を，まず，モンスーン・アジア地域を 特定した上で，北東アジアに打ける連携の要素とそ の関係を順次検討するかたちで進める。すなわち， 1）北東アジアを含むモンスーン・アジアを基層と して捉え, 地域の特定と特質を確認する。ここでは, ケッペンの気候図を用い，アジアに抢いて年中降雨 $(\mathrm{f})$, 冬季少雨 $(\mathrm{w})$, モンスーン $(\mathrm{m})$ とされる気 候区分をカバーする地域 ${ }^{3)}$ をモンーン・アジアと し，そこに含ま机る経済圏を特定する。

つぎに，2）モンスーン・アジア地域と他地域を
経済活動人口（農業）一人当たりの耕地面積（FAO faostat）や年間降水量（FAO: aquastat）等により比較 し，域内に共通する農業生産の特徵を明らかにする。 さらに，3）モンスーン・アジアを母集団とした ときの日韓台の特異性と 3 つの経済圏の同質性を経 済発展の程度（IMF：一人当たり GDP）や農業保 護率（K. Anderson, W. Martin et al. 2009: NRA）等か ら考察し，最後に 4）日韓台と中国の緊密性の高ま りを食品貿易の取引量（RIETI: TID2009）や中国農 業・農政の動向等から比較検討する。

\section{4. モンスーン・アジアの地理的分布}

モンスーン・アジアは，極東ロシアからインドに 及ぶ地域に位置するとされる（倉嶋：1972）。前項 で示した手順でこの地域を特定すると，図1で太線 の下部に位置する経済圈がモンスーン・アジアに該 当すると考光られる。ここに含まれるのは，バング ラデシュ,ブータン，ブルネイ，カンボジア，中国， インド，インドネシア，日本，韓国，北朝鮮，ラオ ス, マレーシア，ミャンマー，ネパール，フィリピ ン, シンガポール, スリランカ, タイ、チモール, ヴェ トナム，台湾の 21 経済圈である。

\section{5. モンスーン・アジアの特質}

モンスーン・アジアは高温多湿であり，夏季の降 雨量が多い「「湿ったアジア」とも呼ばれる（倉嶋： 1972)。また，この地域は人口が稠密であることで も知られている.

そこで，年間降雨量と一人当たりの耕地面積をモ ンスーン・アジア地域と他の地域を比較すると, 図 2 のようになる。図の近似曲線（点線表示）でわか

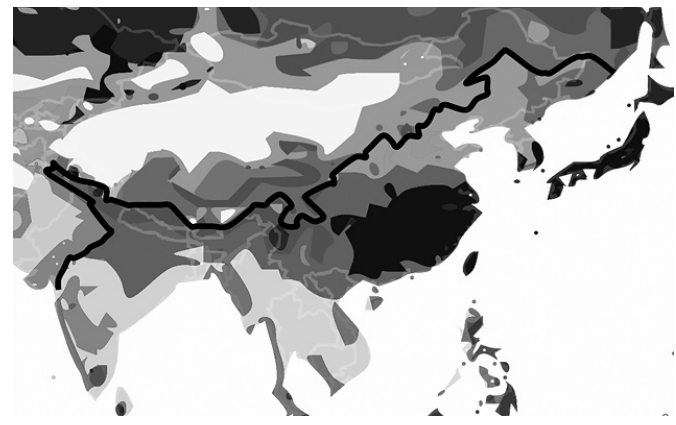

図 1. モンスーン・アジアの地理的分布

注）ケッペン気候図（Peel（2007)）飞筆者が加筆して作成. 
るよらに両者は反比例の関係にあり，相関係数は, -0.58（p 值 =0.001）となっている，また，モンスー ン・アジアの経済圈は欧州や南北アメリカの主要経 済圈 ${ }^{4)}$ と明瞭に分離されていることがわかる。

年間降雨量を $p$, 一人当たりの耕地面積を $l$ とする と，(1）式で示す判別直線によりモンスーン・アジ アとそれ以外の地域は効率よく分離できる ${ }^{5)}$ (図 2).

$$
p=(3.55994 * l-9.31665) / 0.00172
$$

夏に湿潤なモンスーン・アジアは水稲作に適して 打り，コメの依存度が高い。世界のコメの生産量や 作付面積はモンスーン・アジアに集中しており，そ のシェアは 9 割近くに達している (図 3 参照).

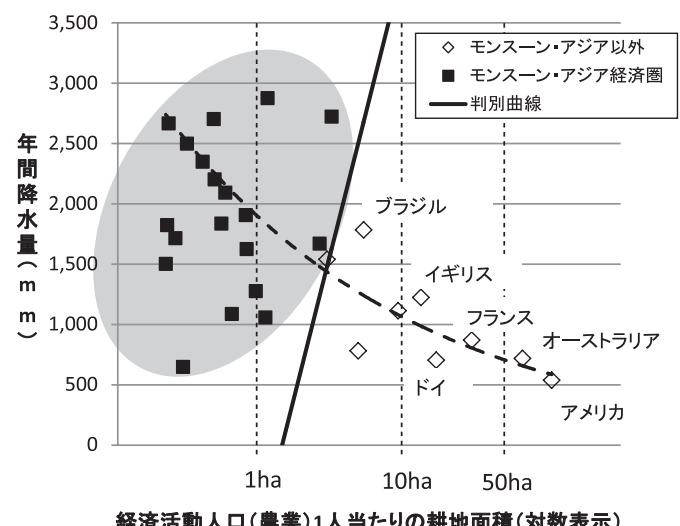

図 2.モンスーン・アジア農業の特質

注）経済活動人口（農業）及び耕地面積（arable land）は FAOSTATによる. また, 年間降水量は FAO, aquastat による，点線は分布の近似曲線（指数）を示す.

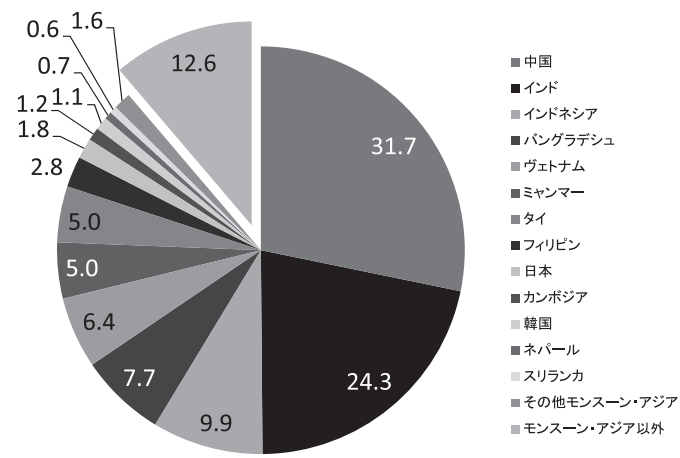

図 3.世界コメ市場におけるモンスーン・アジアの シェア

注）台湾については，台湾農業委員会（COE） 98 年農業 統計年報による。その他のデータはFAOSTATによる.
オーシマは，かつてのコメの単位面積当たりの収 穫量が小麦よりもはるかに高く，その人口扶養力が 現在のモンスーン・アジアの稠密な人口分布を形成 したとする（オーシマ(1989）：p.44）.

結果として，農業従事者あたりの耕地面積は小さ く, アメリカやオーストラリアなどの新開国や欧州 などと比較すると，士地利用型の作物（穀物など） の競争力は著しく低い.

モンスーン・アジアのこらした特性は, アジアの 広い地域にみられる共通性であるが，北東アジアを 支える基層でもあり，連携を支える第 1 の基盤と なっている.

\section{6. 食料純輸入先進経済圏としての共通性}

北東アジアの連携を支える第 2 の基盤は，急速な 経済発展と高い農業保護率にある。図 4 はモンス一 ン・アジアの主要経済圏に打ける一人当たりの GDP と農業保護率（名目助成率）を比較したもの である。困 4 では, 1980 年代の前半から 2000 年代 の前半までの 5 期間について GDP と保護率の平均 を算出して，その変化を示している（図中の台湾の 事例参照).

この図から，日韓台の一人当たりの GDPは 10,000 ドルを上回り，農業保護率は 50\%を越えて いることがわかる．両指標の水準は，他のモンスー ン・アジア経済圈のそれを遙かに上回って扣り，異 質な集団を形成している.

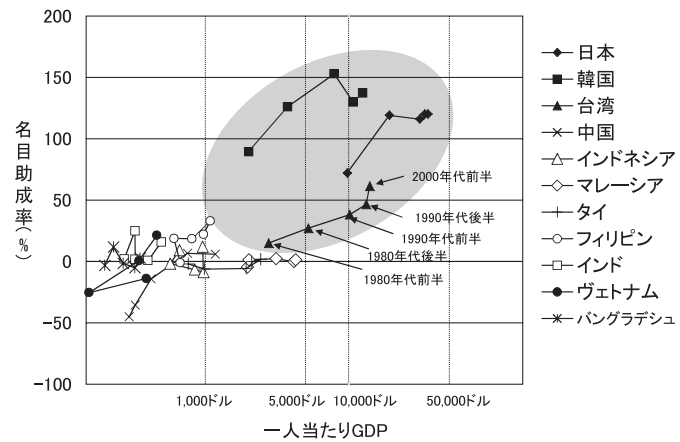

図 4. モンスーン・アジアにおける 1 人当たり

\section{GDP と名目農業保護率の変化}

注）名目保護率については, Kym Anderson and Will Martin （2009），及び，本間（2010）を基に作成. また，1人 当たり GDPについては，International Monetary Fund, World Economic Outlook Database, April 2010 による. 
日韓台はいずれも農地改革の後, 急速な経済成長 を経験した，欧米と比較して「圧縮された」経済成 長とも呼ばれるこの成長は, 農工間の所得格差を一 気に顕在化させた（渡辺・金 1996）。また，工業製 品の輸出増加が, 自国通貨の切り上げを通じて農産 物輸入を促進し，所得格差をさらに拡大してきた経 緯がある。

農工間の所得格差へ対処するために, 日韓台は世 界で最も高い水準の農業保護政策を採用してきた. しかし，今後はWTO の国際貿易ルールに沿った農 業保護水準の削減が避けられない，農業保護政策は 高い水準にあるとはい光，日韓台は寸でに大量の穀 物を海外から輸入する食料純輸入経済圏である，食 料自給率をカロリーベースでみるといずれも50\% を下回っている. 安定した食料の確保や農村の社会・ 環境の維持・保全をいかにして図るかは, 日韓台が 直面する共通の課題となっている.

北東アジアで残る 1 つの経済圏である中国はいま のところ, 日韓台とは異質なポジションにある。 1 人当たりの GDP, 農業保護水準ともに低い水準に 留まって抢り，食料純輸入先進経済圏としての性格 は共有できていない。

しかし，中国は日韓台と同様に「圧縮」された経 済発展のただ中にある。2004 年に各種の農業補助 金を導入するとともに，2006 年には農業税を廃止 し，農業搾取から農業保護へと政策の転換を図って いる. したがって, 今後中長期的には, 図 4 にみた 日韓台のグループに接近し, 北東アジアに抢けるよ り高次の連携が実現される可能性は少なくない.

こうした潜在的な動向を合わせて考慮するとき， 食料純輸入先進経済圏としての経済構造は北東アジ ア農業の連携を支える強固な共通性のひとつと位置 ら゙けることができる。

\section{7. 日韓台と中国の食品貿易の増大と不安}

中国は, 図 4 とは異なる形でも他の北東アジア経 済圏との結びつきを強めている，そ饥は，食品貿易 を通じた結びうきである

図 5 は, 日韓台を 1 つの経済圏としてみたときの 中国との食品貿易の取引額及び食品貿易総額に占め るシェアをまとめたものである。過去 20 年間の動 向をみると, 日韓台が中国から輸入した食品の総額 は 20 億ドルから 100 億ドルへと 5 倍に増加し，日
韓台から中国への食品輸出額も 7 千ドルから 7 億 6 千ドルへと 10 倍を超える. 日韓台の食品輸出入額 に占める割合についても，中国からの輸入が $5 \%$ か ら $16 \%$ 几，輸出は1\%から $8 \%$ へと大幅な増加がみ られる。

相互の取引は着実に拡大し, 重みを増している. 中国からの輸入に関しては, 1990 年代の後半に一 旦停滞傾向がみら玌るが，21 世紀になって再び増 加する傾向が顕著である.

貿易量の増大の一方で，中国製冷凍餃子中毒事件 やメラミン粉ミルク事件なぞが中国産食品への不安 感を増大させている。韓国でも中国産食品の安全性 が問題視されて久しい.

こらした不信は，2008 年に中国からの食品輸入 の大幅な減少に繋がり, 中国の農業・食品産業に少 なからぬ打撃を与えている (図 5 参照)。いまや食 品問題は，日韓台にとっても，中国にとっても相互 の協力なしには解決できない課題となっている。 こ のことが連携の第 3 の基盤となる.

な敃，図 5 は日韓台を 1 つと捉えて，中国との取

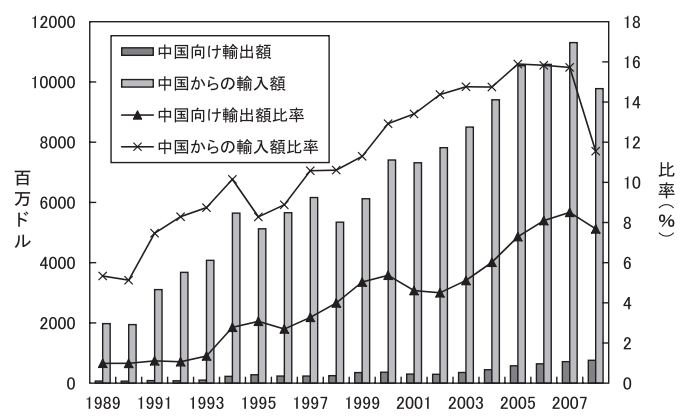

図 5. 日韓台と中国の食品貿易

注）（独）経済産業研究所 RIETI-TID2009 のデータを用 いて作成。

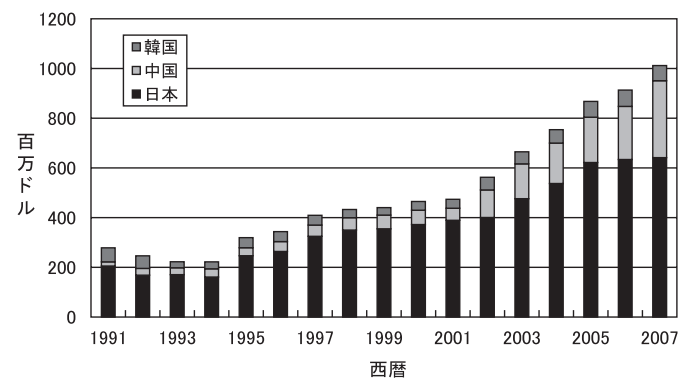

図 6. 北東アジアからの食品輸入動向（台湾）

注) 図 5 に同じ. 


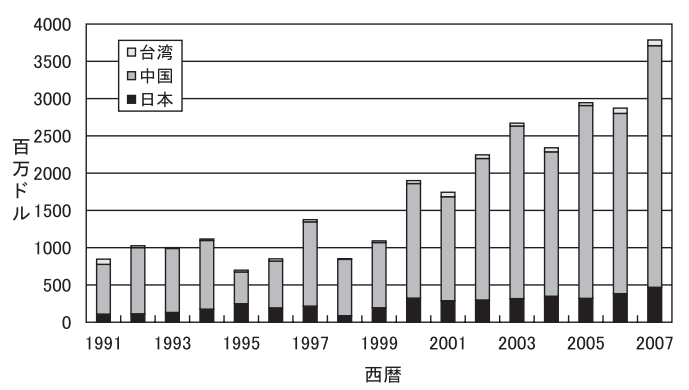

図 7. 北東アジアからの食品輸入動向（韓国）

注）図 5 に同じ.

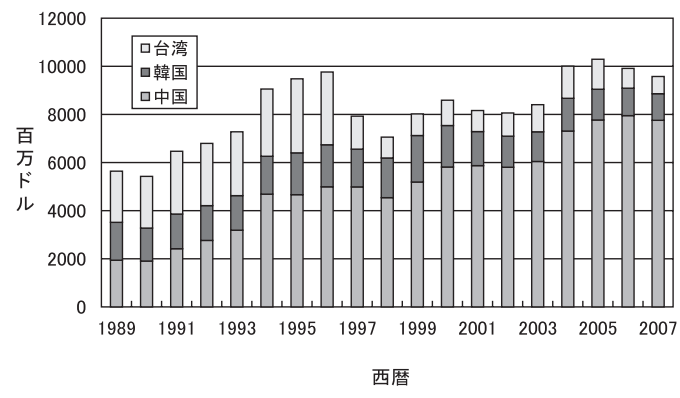

図 8. 北東アジアからの食品輸入動向（日本）

注) 図 5 亿同じ.

引を集計しているが，経済圈ごとにみると，中国と の取引の関係には少なから奴差異がある. 図6 は台 湾の北東アジアの各経済圈からの食品輸入をみたも のである．台湾でも中国の比率は増加しているもの の，依然，日本のシェアは他を圧倒している。

これに対し，図７にみる韓国の動向は逆であり， 中国依存を大幅に高めている. 日本はその中間に位 置する (図 8 参照)。2010 年に成立した中台経済協 力枠組夕協定 (ECFA) 飞打いても，台湾は中国産 農産物の市場開放をして扔らず，この構造は当分維 持されそらである。こうした相互依存関係の差異は 今後の北東アジアの連携を考学る際に注意が必要で ある。

\section{8. むすび}

北東アジア連携の基盤構造は以下のように整理で きる。

まず，北東アジア農業はアジア・モンスーン地域 に立地し，これが第 1 の基盤となる.

北東アジアの 4 つの経済圏のらち, 日韓台は急速 な経済発展により，他のモンスーン・アジアの諸経
済圈とは異質な集団を形成している。その発展は短 期間に「压縮」されて和り, 農業・農村に打汀る構 造調整は容易でない，このため，高い水準の農業保 護が余儀なくされている．WTO の国際規律は，こ の保護水準の引き下げを要請して打り，日韓台は食 料の安定的な供給や農村の維持や環境保全などの課 題を共有している.

中国については現時点においてこうしたグループ に属する状沉にはないが，急速な経済成長と農業保 護への政策転換などからみて，今後食料純輸入先進 経済圏としての性格を強める可能性は少なくない， これらの点が連携を支光る第 2 の基盤となる。

日韓台の中国との間の食料貿易の拡大は，両者の 関係を深めてきたが，日韓台と中国の経済発展の差 異を軸にした域内の農産物・食品ネットワークは, 日韓台と新大陸諸国との貿易とは性格を異にする点 を見落としてはならない，アメリカやオーストラリ アからの農産物・食品の輸入は圧倒的な生産性の格 差が前提にあり，日韓台にとってこれらの国は輸入 相手国として純化している。 これに対し，中国は既 に述ベた通り，モンスーン・アジアに立地し，食料 純輸入圈への転換を始めている経済圈である. 今後, 同質性を高める可能性の高い中国に対しては，食料 純輸入経済圏として先行する日韓台の観点から生産 から流通までの技術や制度の移転を含んだ多角的で 重層的な協力関係を構築しらる相手として位置づけ ることができる．これが第 3 の基盤となる.

こうした日韓台と中国との関係性が，北東アジア 以外のモンスーン・アジア経済圈に打いて再現され る可能性は少なくない。したがって，北東アジアの 連携は北東アジアだけを射程に置くのではなく，モ ンスーン・アジアに共通する食と農の問題をも見通 すものとして構想すべきであろう。また，モンスー ン・アジアに打ける重層的な関係の深まりは中長期 的に当該地域に打沙農業の特殊性をWTOなどの 国際機関に打けるルールら゙くりに反映するための交 渉の基礎固めとなっていくに違いない，

[謝辞] 本稿の作成に際しては，日本学術会議農 業経済学分科会（分科会長：生源寺眞一教授）飞抒 ける議論から多くの示唆を得た。また，気候区分に ついては, 駒澤大学文学部・江口卓教授からご助言 を頂いた。記して謝意を表します。 
注 1) 鳥取大学大学院連合農学研究科編 (2009) の第 3 章, 崔世均「東北アジアに抢ける農業貿易の展望と協 力体制」では，域内の農産物貿易や各国（日中韓） の農業構造を踏まえて, 食品安全システムの構築, 農業協力事業の強化, 共通農業政策構想などを提 言している. 協力の必要性については, 市場開放 の要請と多面的機能の縮小といら相反性を克服す るためとして抢り，連携の根拠を構造的に捉えよ らとする視点が明確にされている（pp. 34-35）.

2) 2000 年の時点では, 日本は EUなどと多面的機能 を軸としたフレンズ諸国を形成していたが，その 結束は弱く 2003 年には EU が離脱してしまう（作 山2006). その後は食料輸入国の集団である G10 が結成され一定の成果をあげるものの, 基盤とな る農業の性格は多様であり, 脆弱性を残したまま である.

3）いずれも夏季に多雨・湿潤であるといら性質を持 ち，モンスーン気候の影響が及んでいると考光ら れる地域である.

4）オーストリア, フランス, ドイッ, オランダ, ス イス，英国，アメリカ，ブラジルの 8 カ国を選ん でいる.

5）判別関数の計算は $\mathrm{R}$ 言語を用い手行い. http://aoki2. si.gunma-u.ac.jp/index.html のプログラムを利用し た. 正判別率は $96.4 \% て ゙ あ り ， 28$ のンプルのら ち誤判別はスイスの 1 カ国だけであった.

\section{参考文献}

[1] 今村奈良臣他「東アジア農業の展開論理一中 韓台日を比較する一」，農山漁村文化協会， 1994.

[2]生源寺眞一『農業再建』岩波書店, 2008 .

[3]倉嶋 厚『モンスーン 季節をはこぶ風』河 出書房新社, 1972 .

[4]作山巧『農業の多面的機能を巡る国際交渉』
筑波書房, 2006.

[5]堀口健治「WTO 交渉で日本はアジアと連携で きるか」『農業と経済』2000 年 12 月号, pp. 5-14.

[6]日本農業経済学会「経済グローバリゼーショ ンと農業一東アジア経済圈連携の可能性一」, 『農業経済研究』第 79 巻, 第 2 号, 2007.

[7]地域農林経済学会「グローバリゼーションと 地域農業・農政の展望」, 『農林業問題研究』 第 161 号， 2006.

[8] 辻井 博「日本主導のアジア諸国との連携の 必要性」『農業と経済』2000 年 12 月号, pp. 3.

[9] 鳥取大学大学院連合農学研究科編『WTO 体制 下に打ける東アジア農業の現局面』農林統計 出版, 2009.

[10］日本農業経済学会「東アジアの農産物貿易と 農業・農村」『農業経済研究』第 79 巻, 第 2 号, 2007.

[11] ハリー・T・オーシマ (1989)『モンスーンア ジアの経済発展』頸草書房.

[12］本間正義『現代日本農業の政策過程』慶應義 塾大学出版会, 2010.

［13］渡辺利夫・金 昌男『韓国経済発展論』頸草 書房, 1996.

[14] Kym Anderson and Will Martin ed, Distortions to agricultural incentives in Asia, The World Bank, 2009.

[15] Peel, M. C., B. L. Finlayson and T. A. McMahon, Updated world map of the Köppen-Geiger climate classification, Hydrol. Earth Syst. Sci., vol. 11, pp. 1633-1644, 2007, www.hydrol-earth-systsci.net/11/1633/2007/ 